Revista do CESP, Belo Horizonte, v.36, n.55, p. 125-128, 2016

\title{
MATOS FRIAS, Joana. Cinefilia e cinefobia no modernismo português (vias e desvios). Porto: Edições Afrontamento, 2015. 125p.
}

Patrícia Resende Pereira

Universidade Federal de Minas Gerais (UFMG), Belo Horizonte, Minas Gerais, Brasil patriciarpereira@gmail.com

Data de recebimento: 10 de junho de 2016

Data de aprovação: 20 de setembro de 2016

Nas primeiras décadas do século XX, o cinema, em tom de novidade, ocupava textos das revistas de literatura portuguesa - não só por meio de ensaios, mas, também, como assunto para poemas. É essa relação entre cinema e literatura, tão fortemente marcada por meio da reflexão crítica dos poetas que se aventuraram a pensar o cinema, que Joana Matos Frias investiga nos ensaios que compõem Cinefilia e cinefobia no modernismo português (vias e desvios), publicado pela Edições Afrontamento, do Porto. Na obra, Matos Frias (2015), professora e pesquisadora do Instituto de Literatura Comparada Margarida Losa, da Universidade do Porto, divide os ensaios em duas partes: vias e desvios.

No primeiro capítulo, "A cinematografia das horas absurdas ou $\mathrm{O}$ desassossego fílmico de Fernando Pessoa", primeiro ensaio publicado na seção vias, a estudiosa encontra em Heróstrato e a busca da imortalidade o ponto de partida para discutir a relação que é possível estabelecer entre Pessoa e o cinema. O poeta português, ao contrário dos autores da revista presença, não apresenta um pensamento crítico fortemente marcado pela reflexão sobre o cinema, como é provado pela autora ao recorrer aos textos escritos por Pessoa e também a algumas cartas, como a enviada para o presencista José Régio, na qual "se recusa a responder 
um inquérito sobre cinema porque não sabe o que pensa do cinema" (MATOS FRIAS, 2015, p. 19, itálico da autora).

No entanto, ainda assim, destaca a autora, isso não impede "a possibilidade de lermos uma parte da sua obra à luz de alguns princípios reguladores da imagem cinematográfica" (MATOS FRIAS, 2015, p. 25), como é feito pela crítica. Matos Frias (2015) baseia-se principalmente em poemas escritos pelo heterônimo Álvaro de Campos, pois é na sua obra que se encontram mais facilmente traços do que é chamado pela estudiosa de metalinguagem cinematográfica. Por isso mesmo, não surpreende saber que foi exatamente Campos quem Pessoa sugere que responda as perguntas feitas por Régio sobre cinema.

Provavelmente em razão de sua ligação com as artes visuais, Almada Negreiros se relaciona mais intensamente com o cinema do que Pessoa, o que é discutido por Matos Frias (2015) no segundo capítulo, em "Quem filmou o meu ser enquanto eu sonhava?: O inconsciente cinemático de Almada Negreiros". A relação estabelecida entre Negreiros e o cinema torna-se clara quando Matos Frias (2015) comenta que o poeta participou como ator de $O$ condenado, de Mário Huguin e Stuart Carvalhais, em que interpretou o vilão, além de ter confeccionado cartazes de filmes como parte de seu trabalho como artista plástico. Entretanto, a autora não se limita apenas a repercutir as intervenções de Negreiros na arte cinematográfica, mas discute como o cinema pode ser pensado também em sua obra poética ao investigar o conhecido poema "As quatro manhãs".

Já o terceiro capítulo não se concentra de modo específico nas considerações acerca de um só poeta, como acontece com os dois primeiros, tendo em vista que se empenha em pensar como a revista presença discute a arte cinematográfica, de modo especial na obra dos escritores José Régio e Adolfo Casais Monteiro. Com o título de "Cine presença", o ensaio explora o que Matos Frias (2015, p. 53) define como "a grande luta dos presencistas", que consiste "desde o primeiro momento na afirmação do cinema como Arte, e se Régio é o mais fervoroso de todos nesta cruzada, Casais será o mais consistente na defesa da independência da nova arte em relação às outras".

Maior texto do livro, o capítulo introduz rapidamente algumas considerações dos poetas sobre os cineastas, em um processo que, mesmo breve, não deixa de ser interessante, como quando a autora apresenta os comentários de Régio sobre Manoel de Oliveira, importante diretor 
do cinema português. Régio, que conheceu o cineasta pessoalmente, apresentado por Casais Monteiro, afirma, logo após assistir ao documentário, em curta-metragem, Douro, faina fluvial (1931), "e eis, entre nós, a grande novidade do Douro: ser uma obra de arte" (RÉGIO apud MATOS FRIAS, 2015, p. 57).

A seção vias encerra-se com o capítulo dedicado a José Gomes Ferreira, chamado por Matos Frias (2015, p. 73) de "caçador de imagens", em alusão ao termo cunhado pelo próprio poeta para se referir aos pseudônimos que usava para escrever nas revistas portuguesas de cinema, entre as décadas de 1920 e 1930, o que lhe permitia, em suas palavras, “"escapulir-se' de si mesmo". Com isso, a autora aproveita-se da condição de poeta andarilho, algo proclamado pelo escritor, para discutir sua capacidade de captar imagens em movimento, em um processo tão próprio do cinema.

Menor do que a primeira seção, desvios, composta por dois textos, tem início com "Esse cinema com cheiro: Filme e poesia nos modernismos português e brasileiro", que como o próprio título indica, propõe uma discussão mais abrangente, agora deixando de ter apenas Portugal como o ponto central. Nesse sentido, o cinema brasileiro se faz presente por meio das considerações sobre Mário de Andrade, Vinicius de Moraes e outros poetas nacionais. Ao lado disso, o ensaio destaca que, em 1931, o cinema brasileiro e o português experimentavam "as primeiras manifestações verdadeiramente artísticas da nova arte" (MATOS FRIAS, 2015, p. 88). Em Portugal, havia acabado de estrear o já mencionado Douro, faina fluvial, de Manoel de Oliveira, enquanto, no Brasil, Limite, de Mário Peixoto, ganha destaque.

Por fim, em "A ansiedade do olhar nas Gerações de 27", a pesquisadora investiga as realizações de 1927, ano importante para o cinema, não apenas o português, mas o mundial, pois foi quando o primeiro filme falado, $O$ cantor de jazz, chegou às telas. Em Portugal, aqui o interesse da obra, é publicado o primeiro número da presença, cujos colaboradores, frequentemente mencionados no livro, em muito contribuíram para a discussão que envolve a arte cinematográfica.

Portanto, nota-se que Cinefilia e cinefobia no modernismo português oferece um interessante panorama do cinema português - e, em alguns instantes, mundial - no começo do século XX e dá a ver a maneira como aquela arte, então em seu princípio, gerava uma série de reflexões, ora fascinadas, ora desconfiadas de suas inovações. Ao mesmo 
tempo, por se tratar de uma obra escrita por uma especialista em poesia, os textos poéticos jamais são deixados de lado, sendo também objetos de debate, o que torna possível ao leitor ampliar seus conhecimentos sobre cinema e literatura portuguesa - uma combinação que não envelhece. 